\title{
The labour supply of women in STEM
}

\author{
Eva Schlenker
}

\section{Correspondence:}

e-schlenker@gmx.de

Department of Economics,

University of Hohenheim, 70599

Stuttgart, Germany

\begin{abstract}
The purpose of this paper is to assess the determinants of female labour supply in science, technology, engineering and mathematics (STEM). To account for selection problems, a special type of grouping estimator and a control function approach are implemented. Using data from EU-SILC, the author finds that women, especially mothers, in STEM work more hours, but have a higher probability of being out of the labour force. The estimation results show furthermore that women in STEM work less hours in countries with higher levels of family allowances. However, this effect is small in size compared to the overall effects of larger levels of expenditures on family allowance and child benefits.
\end{abstract}

JEL Classification: J22; J24

Keywords: Female labour supply; STEM; EU-SILC; Grouping estimator

\section{Introduction}

This paper analyses the determinants of female employment behaviour, focussing on science, technology, engineering, and mathematics (STEM). Occupations in STEM have received special interest in academic and political discussions about occupational choice because these occupations have always been dominated by men. Additionally, the quantity and quality of the labour force in STEM is a key issue for economic growth, and the demand for highly skilled workers increases in technology-related occupations in modern societies from continued technological progress (see, e.g., Tsai et al. (2010)). The increase in the demand for engineers and highly skilled technicians is reinforced by the demographic change, i.e., the labour force in general will decline in all industrialised countries due to the aging of societies and emerging globalised markets.

The high level of occupational segregation in STEM is, furthermore, not only an issue in terms of labour market policies, but is also an issue of gender equality. Even though girls outperform boys in educational achievement, women currently continue to earn less than men, face higher risks of living in poverty and are less likely to enter executive positions. One cause of these inequalities between women and men is the enduring occupational segregation. If girls do not choose these fields of study, they cannot take advantage of the promising earnings and career prospects in STEM occupations. Yet even women who pursue scientific or technical studies have a higher probability of not working in STEM occupations compared to men (see OECD (2012)). In contrast to occupational choice, the differences in the employment behaviour of different occupational groups have not been in the focus of academic interest until now.

(ㄷ) 2015 Schlenker; licensee Springer. This is an Open Access article distributed under the terms of the Creative Commons Attribution License (http://creativecommons.org/licenses/by/4.0), which permits unrestricted use, distribution, and reproduction in any medium, provided the original work is properly credited. 
This paper contributes to the understanding of the employment behaviour of women in science, technology, engineering, and mathematics. The focus is on the labour supply of women in different political and cultural settings, especially for the member states of the EU. How political and cultural settings influence women in STEM differently compared to women in other occupations is of prime importance because labour market policies should, in part, aim to increase the female percentage of workers in STEM. However, there exists only a small number of empirical findings that explain how different occupational groups react to labour market policies and how their employment behaviour can be influenced. So far, only little research has been devoted to analysing relations between occupation choices and labour market behaviour.

The empirical analysis in this paper accounts for unobserved heterogeneity by implementing the estimation methodology described by Blundell et al. (1998), which is applied to data from the European Statistics on Income and Living Conditions (EU-SILC). The author finds some crucial differences in the employment behaviour of women in STEM compared to women in other occupations; i.e., women in STEM work significantly more hours, thus reducing the labour supply significantly less if they have young children. The results also show empirical evidence that women in STEM behave significantly differently in countries with high levels of family allowances than women in general.

This paper is structured as follows: In section 2, the author provides a short review of the related literature. Section 3 describes the estimation methodology. The data set and the estimation results are presented in sections 4 and 5. Finally, section 6 concludes.

\section{Theoretical background and related literature}

A large number of theoretical and empirical studies exists that examine gender-specific labour market behaviour (see Altonji and Blank (1999) for an overview). However, there is a dearth of studies that analyse the differences in the employment behaviour between occupational groups. One major novelty of this paper is, therefore, that occupationspecific labour market behaviour is enquired. This paper relies on several strands of literature that are presented in detail in the following.

One existing strand of literature examines gender differences in occupational choice. Even though occupational segregation has been analysed for several decades, economists do not agree on the determinants of occupational segregation. Traditional economic approaches explain occupational segregation either by gender differences in preferences or by taste-based and statistical discrimination (see Polachek (1981); Becker (1957); Phelps (1972) and Arrow (1972) for details on these theories). Bertrand (2011) provides an overview of empirical findings on these theoretical concepts and their enlargements to the psychological concept of gender identity since 2000.

Apart from the vast literature on occupational segregation in general, some studies in sociology and economics focus on the high gender segregation of students in STEM subjects. The scientific interest in these occupations is rising because economies are increasingly knowledge-driven and a fierce competition exists for workers in these occupations. The main findings of these studies are similar to the research results presented above, i.e., the enduring gender gap in STEM cannot be fully explained by gender differences in abilities (see, e.g., OECD (2012)). It is thus supposed that girls and boys choose different subjects because of personal preferences and expectations about labour market outcomes (see, e.g., OECD (2012)). 
Carrell et al. (2010) contribute to this literature by examining the impact of professor gender on the gender gap in science. Using data from the U.S. Air Force Academy, they find that girls perform better in mathematics and science classes if they are taught by a female professor. Their findings agree with Legewie and DiPrete (2014), who show that the attendance of a high school that supports the orientation of girls towards mathematics and science reduces the gender gap in STEM majors significantly. They emphasise the importance of the schooling environment for gender-specific orientation towards these fields of study.

The results of these studies are in line with former findings of American educationalists like Leslie et al. (1998). They emphasize that the percentage of female graduates in STEM can only be increased by actions taken during high school years. Leslie et al. (1998) find also that the influence of peers is the main driving force for girls' decreasing interest in science and mathematics during adolescence. Furthermore, Leslie et al. (1998) analyse the influence of family background. They show that having a father or a mother who works in engineering or science increases a girl's probability of choosing engineering or science as a field of study. The importance of family background has also been found by Jackson et al. (1993). Jackson et al. (1993) also note that women who become engineers do not only tend to have fathers who are engineers but also tend to marry engineers themselves. Empirical studies on the influence of parental occupation, however, show mixed results in different countries. Bergman et al. (2012) show that, in Switzerland, children tend to choose science courses if their parents' occupational status is high. However, the effect is only significant for vocational training. Using longitudinal PISA data, Fernandez et al. (2012) do not find this trend for Uruguay.

Apart from the vast amount of studies on the determinants of gender segregation in education and employment, some empirical research is conducted to examine whether labour market outcomes, especially earnings, differ among occupational groups. Focusing on scientific occupations, Chevalier (2012) finds that it is mainly not the scientific degree itself that induces wage premiums in the United Kingdom but the actual occupational choice. He estimates a wage premium of $18 \%$ for scientific occupations.

Görlitz and Grave (2012) present similar results using data on German university graduates. They find significant wage differences according to the fields of study in Germany; e.g., the raw wage gap of art and humanities compared to engineering is $40 \%$ when entering the labour market. This wage gap persists throughout the employee's career. Furthermore, Görlitz and Grave (2012) show that wage differentials are explained to a larger extent by labour market and firm characteristics than by individual or study-related characteristics. Wahrenburg and Weldi (2007) obtain similar results and conclude that studying humanities and arts is unattractive from an economic perspective, even though $20 \%$ of all first-year students are enrolled in these fields.

As already mentioned, there exists only a very small number of studies on the labour market behaviour of women in STEM. Some noteworthy exceptions are the studies of Minks (1996, 2001) that focus on young women's labour market entry after graduating from STEM. He shows that women who graduate from STEM subjects tend to search longer for their first jobs and to earn less than their male counterparts. These differences are still significant after correcting for university performance. Haffner et al. (2006) examine engineers' career paths during adult life and confirm that female engineers have worse labour market outcomes in terms of earnings and career opportunities than men. 
Women's lower earnings can be caused by fewer years in the labour force because of maternity leave. Using data from the German Microcensus, Schlenker (2009) shows that female engineers face employment interruptions from child-rearing more often than their male colleagues. Female engineers also tend to work part-time or avoid STEM occupations more often than their male counterparts (see Schlenker (2009)). Both part-time work and working outside one's area cause a loss in earnings. However, even if a gender gap in engineers' employment and earnings exists, female engineers supply more labour than highly skilled women in other occupations, most likely because of the wage premiums in STEM occupations (see Schlenker (2009)). Similar results are found for the employment behaviour of female engineers in the U.S. (see Cordero et al. (1994)). In summary, the few existing studies indicate that women in STEM behave differently in terms of labour supply than men. Some differences in employment behaviour may be attributed to overall differences in male and female labour supply. However, women in STEM display some specific characteristics in terms of labour market behaviour.

All empirical studies presented face the problem of selection effects. The question of why some women choose occupations in STEM, whereas many do not, remains unanswered. Therefore, unobserved heterogeneity and inconsistent estimators cannot be denied. This study takes these issues into account by implementing a special type of grouping estimator proposed by Blundell et al. (1998). The details of this estimation strategy are explained in the following.

\section{Identification and estimation strategy}

\subsection{A specification of labour supply}

Following the method introduced by Blundell et al. (1998), the author specifies the equation for a women i's number of hours worked per week $(h)$ in year $t$ as follows

$$
h_{i t}=\alpha+\beta \log \left(w_{i t}\right)+\gamma \mu_{i t}+\epsilon_{i t},
$$

where $w$ is hourly net wage. $\mu$ represents non-wife income, defined as the difference between the net household income $(c)$ and woman's net wage (wh), i.e., $\mu=c-w h$. This definition of non-wife income is consistent with Wagenhals (2000). Because consumption is not reported in my data set, I cannot apply the definition used by Blundell et al. (1998), which defines non-wife income as the difference between consumption and a woman's net wage. $\epsilon_{i t}$ is the error term. $\alpha, \beta$ and $\gamma$ denote the regression parameters to be estimated.

Technical problems in the estimation of this equation can occur because the error terms $\epsilon_{i t}$ are expected to be serially correlated, correlated with the explanatory variables, and may also be dependent across individuals, reflecting some macroeconomic developments (see Blundell et al. (1998)). Mroz (1987) describes other reasons why labour supply effects are difficult to estimate, e.g., (nonlinear) tax schedules and differences in individu-

als' tastes for work and consumption are some of the typical problems which researchers face.

To counter these identification problems, Blundell et al. (1998) propose a grouping estimator that uses pooled cross-sectional data. The key issue in their estimation strategy is the definition of groups whose hourly net wages and other net income develop differently over time. Blundell et al. (1998) assume that unobserved differences in the average labour supply of the defined groups can be fully accounted for by additive group and time 
effects. They also add the assumption of linear conditional expectations. According to these assumptions, Blundell et al. (1998) implement a generalised Wald estimator ${ }^{1}$. This estimator is the difference-in-differences estimator in the case of only two groups and two time periods and can, therefore, be considered as a generalised difference-in-differences approach.

Following the method of Blundell et al. (1998), the author defines groups that face different variations in their net wages and other types of income. Therefore, the data are divided by the year of the survey, 10-year birth cohort, educational level, geographical area and working in STEM. There must be a sufficient number of individuals per group in the data set. Because of that limitation, the author uses only two educational groups and six groups of member states of the EU. Concerning educational attainment, the first group comprises women who attained (upper) secondary education or less (attained ISCED level $0-3)$. The second educational group includes women with post-secondary education or tertiary education (attained ISCED level 4-6). The EU is divided into six groups of member states in accordance to similarities in culture, history and institutional setting. These groups refer to the classification of countries introduced by Esping-Andersen (1990, 1999). The author forms the following groups of member states of the EU: (1) Scandinavia (Denmark, Finland, Sweden), (2) German-speaking countries (Austria, Germany), (3) Western European countries (Belgium, France, Luxembourg, the Netherlands), (4) AngloSaxon countries (Ireland, United Kingdom), (5) Southern European countries (Cyprus, Greece, Italy, Spain, Portugal) and (6) Eastern European countries, including countries that were formerly part of the Union of Soviet Socialist Republics (Bulgaria, Czech Republic, Estonia, Latvia, Lithuania, Hungary, Poland, Romania, Slovenia, Slovak Republic). Using these definitions, the author forms 72 groups for every survey year. The estimates include 216 groups after the application of the classification to a pooled data set of three survey years $(2007,2008,2009)$.

The author expects that the mentioned characteristics are affected differently by institutional settings and labour market environments. The distribution and changes in group average net wages and group average non-wife income (especially partner's income) differ across groups; e.g., technical progress affects labour demand and, therefore, wages differently for different groups. The interaction of group and time effects are excluded from the estimation function of weekly hours of work $h$. This is implied by the assumption that the average difference in labour supply between groups is time-invariant (see Blundell et al. (1998)).

\subsection{Implementation of the estimator}

The estimator is implemented by using a control function approach (see Blundell et al. (1998)). Initially, the author estimates three reduced forms using labour participation, log wages and non-wife income as dependent variables. A Heckman selection model ${ }^{2}$ is applied to regress labour participation on a complete set of time and group interactions and demographic variables. The participation equation is estimated for the whole sample. Non-working women are excluded from the estimation sample of log wages and non-wife income. The author performs a regression of log wages and non-wife income on a complete set of time and group interactions and demographic variables using ordinary least squares (OLS). The author then computes the residuals for both regressions. 
The parameters of the labour supply equation can be estimated consistently using OLS. The estimation equation is of the following form:

$$
h_{i t}=a_{g}+m_{t}+\boldsymbol{\alpha}^{\prime} \mathbf{x}_{i t}+\beta \log \left(w_{i t}\right)+\gamma \mu_{i t}+\delta^{p} \hat{v}_{i t}^{p}+\delta^{w} \hat{v}_{i t}^{w}+\delta^{\mu} \hat{v}_{i t}^{\mu}+\epsilon_{i t},
$$

where $a_{g}$ and $m_{t}$ represent group and time effects, respectively, $\mathbf{x}_{i t}$ is a vector containing socio-demographic variables, $w$ is hourly net wage, and $\mu$ is non-wife income. The $\hat{v}$ 's are the residuals from the reduced forms. More precisely, $\hat{v}_{i t}^{p}$ is the estimated inverse Mill's ratio from labour participation, $\hat{v}_{i t}^{w}$ and $\hat{v}_{i t}^{\mu}$ correspond to estimated residuals from $\log$ wages and other income, respectively. $\epsilon_{i t}$ is the error term. I want to estimate the regression parameters $\boldsymbol{\alpha}, \beta, \gamma$ and $\delta^{i}$.

This computational approach gives numerically identical results to grouping estimators. Furthermore, the $t$ statistics of the estimated coefficients $\delta^{p}, \delta^{w}$ and $\delta^{\mu}$ can be used to test for exogeneity (see Blundell (1986)). As described above, 216 groups are used in the data set. Three groups are excluded from the estimation because they comprise less than 50 individuals. The average cell size for the other groups is 1,042 individuals $^{3}$.

\section{Data set and sample descriptives}

The author uses data from the EU-SILC, an official survey designed to describe and to explain living conditions in all EU member states. For the analysis, the cross sectional data sets of the waves 2007, 2008 and 2009 are pooled. The data set comprises females who were born between 1960 and 1990. The author limits the analysis to these birth cohorts because it can be expected that most of these women have finished their education but are not yet retired. Women who are in full-time education are excluded from the data set. The data set is also limited to women who are neither in military and social services nor retired. The data set comprises approximately 205,000 individuals.

The variable of main interest is the weekly number of working hours. Women in the data set work 35 hours per week on average. Approximately $20 \%$ of all individuals do not participate in the labour market. Furthermore, sample descriptives show that the individuals in the data set have 1.3 children, on average, and approximately $15 \%$ of them have a child three years old or younger. Table 1 depicts the summary statistics of the data set.

For a comparison of labour market behaviour between women in STEM and other occupations, the dummy variable stem is introduced that equals 1 if a women works or has worked in the fields of science, technology, engineering, and mathematics. The author isolates women in STEM using the 2-digit ISCO88 classification available in EU-SILC ${ }^{4}$. Hence, a woman is classified as working in STEM if she indicates one of the following

Table 1 Summary statistics in the data set

\begin{tabular}{llllll}
\hline Variable & Mean & Std. Dev. & min & max & N \\
\hline Labour participation & 0.795 & 0.403 & 0 & 1 & 204610 \\
Hours worked per week & 35.94 & 9.298 & 1 & 99 & 161879 \\
Hourly wage in PPS & 9.492 & 10.323 & 0.001 & 706.526 & 161879 \\
Non-wife income in 1000 PPS & 24.886 & 30.576 & 0 & 2410.095 & 204610 \\
Year of birth & 1971.316 & 7.611 & 1960 & 1990 & 204610 \\
Highest ISED level attained & 3.487 & 1.149 & 0 & 5 & 204610 \\
Youngest child 0-3 years & 0.155 & 0.362 & 0 & 1 & 204610 \\
Youngest child 4-6 years & 0.109 & 0.311 & 0 & 1 & 204610 \\
Youngest child 7-10 years & 0.125 & 0.33 & 0 & 1 & 204610 \\
\hline
\end{tabular}


ISCO- 88 codes: $21,31,71-73,82,93$. Approximately $11 \%$ of the individuals in the data set are indicated as women working in STEM.

Figure 1 illustrates the percentage of women in STEM per country. The lowest percentage of women in STEM is found in Luxembourg, Greece, and the Netherland according to my data set. Eastern European countries display relatively high percentages of women in STEM compared to other European countries. Similar results are found by OECD (2012); under a communist government, policies promoted young women's studies of STEM subjects. After the breakdown of the Soviet regime, however, the percentage of women in STEM has again decreased. The percentage of women in STEM in the data set is slightly lower than reported by other sources. This may be because the classification of occupations is only available at the 2-digit level in EU-SILC. Therefore, some differences in the definition of STEM occupations can occur compared to more detailed occupational classifications. Table 2 depicts the summary statistics of the data set for women in STEM and women in other occupations.

Sample descriptives display some differences in the labour market behaviour between women in STEM and women in other occupations. Table 2 shows that the weekly hours of work differ between these two groups: women in STEM work, on average, more hours per week than women in other occupations (38.4 versus 35.7). However, the labour participation of women in STEM is lower: a woman's likelihood to participate in the labour market increases by approximately 5 percentage points if the woman works in another occupation compared to working in STEM. These findings indicate that once women are in the STEM labour force, they work more hours. I adjust the data to account for the number of children, including dummy variables to indicate a child younger than 3,6 , and 10 years $^{5}$. The author does not find relevant differences between women in STEM and in other occupations concerning the percentage of individuals with small children. The differences in ISCED educational levels attained as well as birth years are not economically significant between women in STEM and women in other occupations. To account for tertiary education, a dummy variable high educational level is defined that equals 1 if the ISCED level attained is 4 or 5 .

The level of wages and non-wife income are important economic predictors of labour supply. The author employs hourly net wages and household's non-wife income to account for income effects ${ }^{6}$. However, several specifics of the EU-SILC must be taken into

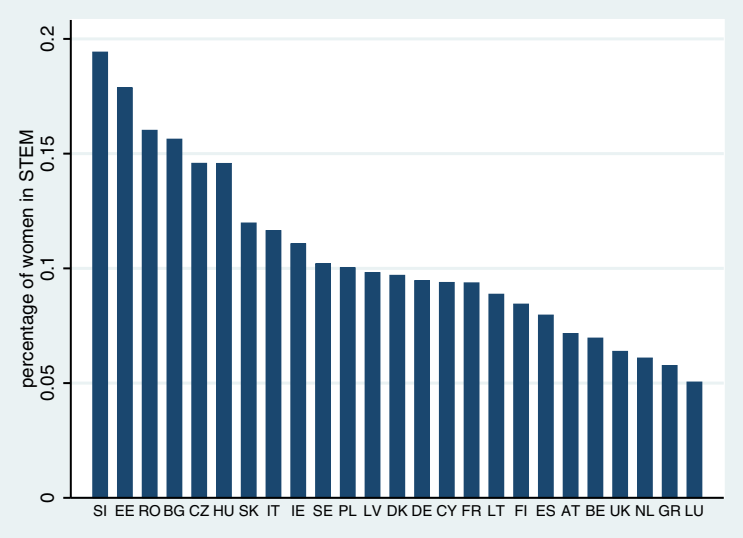

Figure 1 Percentage of women in STEM per country in the data set. 
Table 2 Summary statistics of women in STEM and in other occupations

\begin{tabular}{llllll}
\hline Variable & Mean & Std. Dev. & min & max & N \\
\hline Women in STEM & & & & & \\
Labour participation & 0.747 & 0.435 & 0 & 1 & 22692 \\
Hours worked per week & 38.351 & 6.890 & 1 & 84 & 16877 \\
Hourly wage in PPS & 7.743 & 9.432 & 0.001 & 320.11 & 16877 \\
Non-wife income in 1000 PPS & 20.19 & 25.407 & 0 & 487.7 & 22692 \\
Year of birth & 1971.031 & 7.504 & 1960 & 1990 & 22692 \\
High educational level & 0.260 & 0.439 & 0 & 1 & 22692 \\
Youngest child 0-3 years & 0.143 & 0.35 & 0 & 1 & 22692 \\
Youngest child 4-6 years & 0.101 & 0.301 & 0 & 1 & 22692 \\
Youngest child 7-10 years & 0.122 & 0.327 & 0 & 1 & 22692 \\
\hline Women in other occupations & & & & & 181918 \\
Labour participation & 0.801 & 0.399 & 0 & 1 & 145002 \\
Hours worked per week & 35.66 & 9.499 & 1 & 99 & 145002 \\
Hourly wage in PPS & 9.696 & 10.402 & 0.002 & 706.526 & 181918 \\
Non-wife income in 1000 PPS & 25.472 & 31.111 & 0 & 2410.095 & 181918 \\
Year of birth & 1971.351 & 7.624 & 1960 & 1990 & 181918 \\
High educational level & 0.379 & 0.485 & 0 & 1 & 181918 \\
Youngest child 0-3 years & 0.157 & 0.364 & 0 & 1 & 181918 \\
Youngest child 4-6 years & 0.11 & 0.312 & 0 & 1 & 181918 \\
Youngest child 7-10 years & 0.125 & 0.331 & 0 & 1 & \\
\hline
\end{tabular}

account when using income variables. On the one hand, all income variables are measured in national currency and refer to the year before the survey. On the other hand, the weekly hours of work and the employment status refer to the date of the interview. This can cause measurement errors if the employment status and/or the job have changed (see Engel and Schaffner (2012)). However, many empirical studies use the available information on wages and earnings as proxies to calculate (actual) hourly wages (see, e.g., Badescu et al. (2010) and Glocker and Steiner (2011)). I also follow this approach ${ }^{7}$. The nonwife income is calculated as the difference between the net household income and the woman's net wage. At first, all wage and income variables are converted into euros, and then they are converted into purchase power standards (PPS), taking the countries' different price levels into account. The rates of exchange are provided by Eurostat via an online database ${ }^{8}$.

The average hourly wage is approximately 9.5 euros. However, the distribution of wages is right-skewed and scattered. Astonishingly, the author finds that the average hourly wages of women in STEM are lower on average compared to other occupations in the data set (see Table 2). This is surprising because occupations in STEM are known to have high wage premiums. This contradiction in the sample is caused by different wage patterns in Eastern European countries. Occupations in STEM reflect lower educational levels and wages in these countries because of specifics in these countries' histories (see OECD (2012)). If Eastern European countries are excluded, the data set shows the expected right-skewed wage distribution with higher wages, on average, for occupations in STEM. Additionally, higher levels of education show higher levels of wages than lower and middle levels of education.

To sum up, the descriptives show some differences between women in STEM and women in other occupations. Working in part-time jobs seems to occur less often 
in STEM, while labour participation is higher in other occupations. Whether sociodemographic variables or selection effects can explain these differences is analysed in the following section that discusses the estimation results.

\section{Empirical results}

\subsection{Estimation results of the reduced forms}

Tables 3, 4, and 5 present the estimation results of the reduced forms for labour participation, log hourly wages, and other non-wife income. As described in section 3 , the estimation results of the three reduced forms are used to compute residuals which are included in the final estimation of labour supply.

Table 3 presents the estimation results of a probit regression for labour participation. The estimates agree with economic theory, i.e., the author finds that having small children significantly reduces women's likelihood of labour participation. The estimation results show that the younger a woman's children are, the lower is her likelihood to participate in the labour market. The reduced form also includes dummy variables for groups and time as well as a full set of interactions. The interaction effects of groups which are excluded because of multicollinearity are set to zero. Additionally, the author accounts for countryspecific fixed effects.

Table 4 shows the estimated coefficients of the reduced form for log hourly wages. The estimation equation includes group and time effects and a full set of interaction terms and country fixed effects. Additionally, the estimated inverse Mills' ratio of the Heckman selection model and demographic variables are included.

The estimated coefficient of the inverse Mill's ratio is significantly positive ( $p$-value: 0.000). This finding implies selection effects. The interactions of time and group effects are also jointly significant in the reduced form. The interaction effects of groups which are excluded due to multicollinearity are again set to zero. The other estimation coefficients are again in line with economic theory, i.e., having young children significantly reduces a woman's hourly wages because mothers of young children often work in part-time jobs or as mini-jobbers with low levels of earnings.

The last reduced form regresses non-wife income on demographic variables, group and time effects and their interactions. Country fixed effects are also included. The estimation results are presented in Table 5. The author finds again that the estimation results agree with economic theory, showing a significant increase in non-wife income if women have small children. This is caused by the lower labour participation of young mothers and the provision of family allowances for (young) children by all EU member states. The interactions of time and group effects are again jointly significant. The interaction effects of groups which are excluded due to multicollinearity are set to zero again.

Table 3 Reduced form: labour participation

\begin{tabular}{lc}
\hline & Labour participation \\
\hline Youngest child 0-3 years & $-0.851^{* * *}$ \\
Youngest child 4-6 years & $(0.00867)$ \\
Youngest child 7-10 years & $-0.384^{* * *}$ \\
& $(0.00978)$ \\
\end{tabular}

Standard errors in parentheses. $+p<0.1,{ }^{*} p<0.05,{ }^{* *} p<0.01,{ }^{* * *} p<0.001$.

Complete set of group effects and time effects as well as a full set of interactions is included.

Additionally, country fixed effects are controlled for. 
Table 4 Reduced form: log wage (in PPS)

\begin{tabular}{lc}
\hline & Log wage \\
\hline Youngest child 0-3 years & $-0.255^{* * *}$ \\
Youngest child 4-6 years & $(0.0247)$ \\
& $-0.0866^{* * *}$ \\
Youngest child 7-10 years & $(0.0120)$ \\
Hazard rate & $-0.0541^{* * *}$ \\
& $(0.00836)$ \\
\hline
\end{tabular}

Standard errors in parentheses. $+p<0.1,{ }^{*} p<0.05,{ }^{* *} p<0.01,{ }^{* * *} p<0.001$.

Complete set of group effects and time effects as well as a full set of interactions is included.

Additionally, country fixed effects are controlled for.

\subsection{Baseline models for labour supply}

After the estimation of the reduced forms, the estimated residuals are included in the final estimation of labour supply measured by the number of weekly hours of work. Table 6 presents the estimation results. All columns include dummy variables for group and time effects as well as fixed effects for countries and for 10-year birth cohorts. The effects of country, time, and group are jointly significant for all specifications ${ }^{9}$.

The estimations indicate that wages are endogenous for the parameters of the equation of labour supply. This finding is highly significant throughout all specifications ( $p$-value of residuals of log wage: 0.000). Empirical findings concerning the exogeneity of labour participation are mixed: the residuals of the reduced forms for labour participation (hazard rate) are only significant in three out of four specification. Other non-wife income seems to be exogenous for the equation of labour supply. The estimated coefficient of residuals of non-wife income are insignificant for all specifications.

Column (1) presents a baseline model for all women. The signs as well as the sizes of the estimated coefficients are not surprising. If a woman has (young) children, she works significantly fewer hours per week. The number of weekly hours worked is also reduced if a woman faces lower hourly wages or if a woman has higher income from other sources. However, these coefficients are not significant. The author finds a significant effect of a high level of education: women who have attained an ISCED level of 4 or 5 work approximately 1.3 hours more per week.

Column (2) represents an extension of the baseline model and compares the labour supply of women in STEM with the female labour supply in other occupations. The author finds significant differences in the labour supply of women in STEM compared to women in other occupations. Women in STEM work approximately 7 hours more per week. This finding is highly significant. The estimated model also shows that the overall negative

Table 5 Reduced form: non-wife income (in PPS)

\begin{tabular}{lc}
\hline & Non-wife income \\
\hline Youngest child 0-3 years & $4.165^{* * *}$ \\
Youngest child 4-6 years & $(0.244)$ \\
Youngest child 7-10 years & $2.299^{* * *}$ \\
& $(0.273)$ \\
\hline
\end{tabular}

Standard errors in parentheses. $+p<0.1,{ }^{*} p<0.05,{ }^{* *} p<0.01,{ }^{* * *} p<0.001$.

Complete set of group effects and time effects as well as a full set of interactions is included.

Additionally, country fixed effects are controlled for. 
Table 6 Regression for hours worked (income in PPS)

\begin{tabular}{|c|c|c|c|c|}
\hline & (1) & (2) & (3) & (4) \\
\hline Youngest child $0-3$ years & $\begin{array}{l}-3.473^{* * *} \\
(0.239)\end{array}$ & $\begin{array}{l}-3.565^{* * *} \\
(0.240)\end{array}$ & $\begin{array}{l}-3.271^{* * *} \\
(0.245)\end{array}$ & $\begin{array}{l}-3.516^{* * *} \\
(0.246)\end{array}$ \\
\hline Youngest child $4-6$ years & $\begin{array}{l}-3.237^{* * *} \\
(0.121)\end{array}$ & $\begin{array}{l}-3.349^{* * *} \\
(0.123)\end{array}$ & $\begin{array}{l}-3.154^{* * *} \\
(0.123)\end{array}$ & $\begin{array}{l}-3.327^{* * *} \\
(0.125)\end{array}$ \\
\hline Youngest child $7-10$ years & $\begin{array}{l}-2.655^{* * *} \\
(0.0876)\end{array}$ & $\begin{array}{l}-2.775^{* * *} \\
(0.0903)\end{array}$ & $\begin{array}{l}-2.595^{* * *} \\
(0.0889)\end{array}$ & $\begin{array}{l}-2.751^{* * *} \\
(0.0916)\end{array}$ \\
\hline High education & $\begin{array}{l}1.295^{* * *} \\
(0.0464)\end{array}$ & $\begin{array}{l}1.295^{* * *} \\
(0.0464)\end{array}$ & $\begin{array}{l}1.298^{* * *} \\
(0.0464)\end{array}$ & $\begin{array}{l}1.334^{* * *} \\
(0.0465)\end{array}$ \\
\hline Log wage & $\begin{array}{l}0.0215 \\
(0.165)\end{array}$ & $\begin{array}{l}0.0202 \\
(0.165)\end{array}$ & $\begin{array}{l}0.743^{* * * *} \\
(0.218)\end{array}$ & $\begin{array}{l}0.542^{*} \\
(0.218)\end{array}$ \\
\hline Non-wife income & $\begin{array}{l}-0.0140 \\
(0.0115)\end{array}$ & $\begin{array}{l}-0.0137 \\
(0.0115)\end{array}$ & $\begin{array}{l}-0.0400^{* *} \\
(0.0132)\end{array}$ & $\begin{array}{l}-0.0389 * * \\
(0.0132)\end{array}$ \\
\hline Hazard rate & $\begin{array}{l}-1.112^{*} \\
(0.530)\end{array}$ & $\begin{array}{l}-1.126^{*} \\
(0.530)\end{array}$ & $\begin{array}{l}-1.173^{*} \\
(0.532)\end{array}$ & $\begin{array}{l}-0.871 \\
(0.532)\end{array}$ \\
\hline Residuals of log wage & $\begin{array}{l}-1.179 * * * \\
(0.168)\end{array}$ & $\begin{array}{l}-1.177^{* * *} \\
(0.168)\end{array}$ & $\begin{array}{l}-1.907^{* * *} \\
(0.219)\end{array}$ & $\begin{array}{l}-1.794^{* * *} \\
(0.220)\end{array}$ \\
\hline Residuals of non-wife income & $\begin{array}{l}0.00877 \\
(0.0115)\end{array}$ & $\begin{array}{l}0.00853 \\
(0.0115)\end{array}$ & $\begin{array}{l}0.0346^{* *} \\
(0.0132)\end{array}$ & $\begin{array}{l}0.0334^{*} \\
(0.0132)\end{array}$ \\
\hline Working in STEM & & $\begin{array}{l}7.082^{* * *} \\
(0.965)\end{array}$ & & $\begin{array}{l}8.040^{* * *} \\
(1.021)\end{array}$ \\
\hline STEM $\times$ youngest child $0-3$ years & & $\begin{array}{l}1.016^{* * *} \\
(0.243)\end{array}$ & & $\begin{array}{l}1.005^{* * *} \\
(0.243)\end{array}$ \\
\hline STEM $\times$ youngest child $4-6$ years & & $\begin{array}{l}1.151^{* * *} \\
(0.239)\end{array}$ & & $\begin{array}{l}1.142^{* * *} \\
(0.239)\end{array}$ \\
\hline STEM $\times$ youngest child $7-10$ years & & $\begin{array}{l}1.174 * * * \\
(0.214)\end{array}$ & & $\begin{array}{l}1.174^{* * *} \\
(0.214)\end{array}$ \\
\hline$\%$ of GDP spent in family allowance (FA) & & & $\begin{array}{l}-1379.5^{* * *} \\
(284.6)\end{array}$ & $\begin{array}{l}-2016.1^{* * *} \\
(289.4)\end{array}$ \\
\hline$\%$ of GDP spent in childcare (CC) & & & $\begin{array}{l}291.9+ \\
(156.5)\end{array}$ & $\begin{array}{l}405.4^{* *} \\
(156.7)\end{array}$ \\
\hline$\%$ in part-time $\times C C$ & & & $\begin{array}{l}-791.0^{* *} \\
(295.9)\end{array}$ & $\begin{array}{l}-1052.4^{* * *} \\
(296.5)\end{array}$ \\
\hline$\%$ in employment x FA & & & $\begin{array}{l}2346.8^{* * *} \\
(455.0)\end{array}$ & $\begin{array}{l}3369.2^{* * *} \\
(462.7)\end{array}$ \\
\hline$\%$ in part-time & & & $\begin{array}{l}-34.68 * * * \\
(4.404)\end{array}$ & $\begin{array}{l}-38.30 * * * \\
(4.412)\end{array}$ \\
\hline$\%$ in employment & & & $\begin{array}{l}-15.36^{* *} \\
(5.231)\end{array}$ & $\begin{array}{l}-10.20+ \\
(5.247)\end{array}$ \\
\hline STEM $\times \%$ of GDP spent in FA & & & & $\begin{array}{l}-38.53+ \\
(20.50)\end{array}$ \\
\hline STEM $\times \%$ of GDP spent in CC & & & & $\begin{array}{l}-138.5^{* * *} \\
(33.54)\end{array}$ \\
\hline$\%$ in STEM & & & & $\begin{array}{l}-39.45^{* * *} \\
(3.335)\end{array}$ \\
\hline Adj. $R^{2}$ & 0.226 & 0.226 & 0.227 & 0.228 \\
\hline $\mathrm{F}$ & $470.7^{* * *}$ & $457.7^{* * *}$ & $446.0^{* * *}$ & $424.8^{* * *}$ \\
\hline N & 161879 & 161879 & 161879 & 161879 \\
\hline
\end{tabular}

Note: Wage and non-wife income in PPS. Standard errors in parentheses. $+p<0.1,{ }^{*} p<0.05,{ }^{* *} p<0.01,{ }^{* * *} p<0.001$. Complete set of group effects and time effects as well as a full set of interactions is included. Additionally, country fixed effects are controlled for.

effect of young children in terms of labour supply is less pronounced if a woman works in STEM: women in STEM reduce their weekly working hours approximately 30 to $40 \%$ less than women in other occupations if their youngest child is younger than 3,6 , and 10 years.

The empirical analysis does not only show differences in the employment patterns of women in STEM and women in other occupations but also examines whether women 
in STEM and women in other occupations react differently to policies concerning family allowances and childcare. These macro variables are included in specifications (3) and (4). I have included the percentage of gross domestic product (GDP) spent on family allowances (FA) and the percentage of GDP spent on daily childcare (CC). Additionally, the percentage of women in employment and their percentage in part-time jobs are inserted into the estimations. Finally, the author accounts for the country's percentage of women in STEM ${ }^{10}$.

Column (3) refers to all women and does not differentiate between occupations. The author finds effects of similar size to those in specification (1) for the socio-demographic variables. However, the positive effect of wages as well as the negative effect of non-wife income are significant in specification (3). Policies are also significantly related to female labour supply; there is a significant positive relationship between weekly working hours and the expenditures on childcare. High levels of expenditures on childcare correspond to a high percentage of women in part-time employment. Higher levels of expenditures on family allowance and child benefits significantly reduce the number of women's weekly working hours.

The author tests for differences between STEM and other occupations in terms of reaction to the discussed policies in column (4) and find some empirical evidence that women in STEM behave slightly differently in terms of labour supply to expenditures on family allowances and childcare. In countries whose governments spend more money on family allowance, women in STEM reverse their weekly working hours even more than women in other occupations. They behave significantly weaker to higher levels of the spending on childcare than women in other occupations. However, the estimated coefficients for both of these effects are small compared to the overall effects. Additionally, the significance of national-level variables vanishes when clustered standard errros are used (see Table 7) ${ }^{11}$.

\subsection{Robustness checks}

To gain a deeper insight into the employment behaviour of women in STEM, the author conducted several robustness checks. The four baseline models presented in the previous subsection are reestimated for several subsamples ${ }^{12}$.

It is a hotly debated topic whether economies face a future lack of workers in STEM. Mainly, the public debate refers to highly educated workers in STEM with vocational or even tertiary education. This is the context for the empirical findings of this paper. Therefore, the author conducts a robustness check by excluding women with low educational levels (attained ISCED level of 0 - 2). The estimated coefficients display a similar pattern of significance and of signs. The sizes of the estimates are also similar. The only exception is the size of the estimated coefficient of the variable STEM. The positive effect of working in STEM is less pronounced for the sample of women who attained an ISCED level of 3 or higher.

A second robustness check is conducted for cohabiting women because many empirical studies that examine female labour supply concentrate on married or women cohabiting with a partner (see, e.g., Blundell et al. (1998) and Wagenhals (2000, 2011)). Married women are of special interest because some tax systems judge married couples' earnings differently from unmarried couples. Additionally, the elasticity of a woman's labour supply has been found to be larger if she lives with a partner. This is explained by the fact that a cohabiting and/or married woman faces less financial constraints if she does not work 
Table 7 Regression for hours worked (income in PPS and SE clustered by countries)

\begin{tabular}{|c|c|c|c|c|}
\hline Youngest child $0-3$ years & $\begin{array}{l}-3.473^{*} \\
(1.641)\end{array}$ & $\begin{array}{l}-3.565^{*} \\
(1.621)\end{array}$ & $\begin{array}{l}-3.271^{+} \\
(1.598)\end{array}$ & $\begin{array}{l}-3.516^{*} \\
(1.549)\end{array}$ \\
\hline Youngest child $4-6$ years & $\begin{array}{l}-3.237^{* *} \\
(0.915)\end{array}$ & $\begin{array}{l}-3.349^{* *} \\
(0.910)\end{array}$ & $\begin{array}{l}-3.154^{* *} \\
(0.914)\end{array}$ & $\begin{array}{l}-3.327^{* *} \\
(0.905)\end{array}$ \\
\hline Youngest child $7-10$ years & $\begin{array}{l}-2.655^{* *} \\
(0.750)\end{array}$ & $\begin{array}{l}-2.775^{* *} \\
(0.752)\end{array}$ & $\begin{array}{l}-2.595^{* *} \\
(0.756)\end{array}$ & $\begin{array}{l}-2.751^{* *} \\
(0.759)\end{array}$ \\
\hline Log wage (PPS) & $\begin{array}{l}0.0215 \\
(0.980)\end{array}$ & $\begin{array}{l}0.0202 \\
(0.979)\end{array}$ & $\begin{array}{l}0.743 \\
(1.223)\end{array}$ & $\begin{array}{l}0.542 \\
(1.015)\end{array}$ \\
\hline Non-wife income (PPS) & $\begin{array}{l}-0.0140 \\
(0.0636)\end{array}$ & $\begin{array}{l}-0.0137 \\
(0.0636)\end{array}$ & $\begin{array}{l}-0.0400 \\
(0.0694)\end{array}$ & $\begin{array}{l}-0.0389 \\
(0.0691)\end{array}$ \\
\hline High education & $\begin{array}{l}1.295^{* *} \\
(0.454)\end{array}$ & $\begin{array}{l}1.295^{* *} \\
(0.454)\end{array}$ & $\begin{array}{l}1.298^{* *} \\
(0.454)\end{array}$ & $\begin{array}{l}1.334^{* *} \\
(0.442)\end{array}$ \\
\hline Hazard rate & $\begin{array}{l}-1.112 \\
(3.591)\end{array}$ & $\begin{array}{l}-1.126 \\
(3.550)\end{array}$ & $\begin{array}{l}-1.173 \\
(3.460)\end{array}$ & $\begin{array}{l}-0.871 \\
(3.431)\end{array}$ \\
\hline Residuals of log wage (PPS) & $\begin{array}{l}-1.179 \\
(0.980)\end{array}$ & $\begin{array}{l}-1.177 \\
(0.979)\end{array}$ & $\begin{array}{l}-1.907 \\
(1.207)\end{array}$ & $\begin{array}{l}-1.794 \\
(1.085)\end{array}$ \\
\hline Residuals of non-wife income (PPS) & $\begin{array}{l}0.00877 \\
(0.0628)\end{array}$ & $\begin{array}{l}0.00853 \\
(0.0628)\end{array}$ & $\begin{array}{l}0.0346 \\
(0.0677)\end{array}$ & $\begin{array}{l}0.0334 \\
(0.0669)\end{array}$ \\
\hline Working in STEM & & $\begin{array}{l}7.082^{* * *} \\
(0.941)\end{array}$ & & $\begin{array}{l}8.040^{* * *} \\
(1.158)\end{array}$ \\
\hline STEM $\times$ youngest child $0-3$ years & & $\begin{array}{l}1.016^{* *} \\
(0.340)\end{array}$ & & $\begin{array}{l}1.005^{* *} \\
(0.334)\end{array}$ \\
\hline STEM $\times$ youngest child $4-6$ years & & $\begin{array}{l}1.151^{* *} \\
(0.340)\end{array}$ & & $\begin{array}{l}1.142^{* *} \\
(0.349)\end{array}$ \\
\hline STEM $\times$ youngest child $7-10$ years & & $\begin{array}{l}1.174^{* *} \\
(0.318)\end{array}$ & & $\begin{array}{l}1.174^{* *} \\
(0.316)\end{array}$ \\
\hline Percentage of GDP spent in family allowance (FA) & & & $\begin{array}{l}-1379.5 \\
(1434.9)\end{array}$ & $\begin{array}{l}-2016.1 \\
(1534.0)\end{array}$ \\
\hline Percentage of GDP spent in childcare (CC) & & & $\begin{array}{l}291.9 \\
(463.2)\end{array}$ & $\begin{array}{l}405.4 \\
(447.2)\end{array}$ \\
\hline Percentage in part-time $\times \mathrm{CC}$ & & & $\begin{array}{l}-791.0 \\
(1259.3)\end{array}$ & $\begin{array}{c}-1052.4 \\
(1187.7)\end{array}$ \\
\hline Percentage in employment $x \mathrm{FA}$ & & & $\begin{array}{l}2346.8 \\
(2416.5)\end{array}$ & $\begin{array}{l}3369.2 \\
(2590.1)\end{array}$ \\
\hline Percentage in parttime & & & $\begin{array}{l}-34.68^{+} \\
(17.92)\end{array}$ & $\begin{array}{l}-38.30^{+} \\
(19.11)\end{array}$ \\
\hline Percentage in employment & & & $\begin{array}{l}-15.36 \\
(17.58)\end{array}$ & $\begin{array}{l}-10.20 \\
(13.76)\end{array}$ \\
\hline STEM $\times$ percentage of GDP spent in FA & & & & $\begin{array}{l}-38.53 \\
(45.79)\end{array}$ \\
\hline STEM $\times$ percentage of GDP spent in CC & & & & $\begin{array}{l}-138.5^{+} \\
(72.28)\end{array}$ \\
\hline Percentage in STEM & & & & $\begin{array}{l}-39.45^{+} \\
(21.14)\end{array}$ \\
\hline $\mathrm{R} 2$ & 0.227 & 0.227 & 0.228 & 0.229 \\
\hline Obs. & 161879 & 161879 & 161879 & 161879 \\
\hline
\end{tabular}

Note: Wage and non-wife income in PPS. Standard errors in parentheses. $+p<0.1,{ }^{*} p<0.05,{ }^{* *} p<0.01,{ }^{* * *} p<0.001$. Complete set of group effects and time effects as well as a full set of interactions is included. Additionally, country fixed effects are controlled for.

or reduces her weekly working hours because a couple can pool their earnings and take advantage of economies of scale (see, e.g., Bick and Fuchs-Schündeln (2012)). Therefore, I use cohabiting women for a further robustness $\operatorname{check}^{13}$. 
The estimation results for cohabiting women show some differences in comparison to the baseline models for all women. The main findings for socio-demographic variables, however, remain unchanged. The empirical results indicate a stronger influence of non-wife income for cohabiting women. Another more surprising difference between the full sample and the subsample of cohabiting women is found: the positive effect of working in STEM in terms of labour supply is not evident for cohabiting women. The estimated coefficient turns insignificant and negative. This may be explained by the fact that women in STEM are often married or living with men who also work in STEM (see, e.g., Leslie et al. (1998)). Because these men also have higher earning potentials because of their occupational fields in most countries, their female partners face less financial pressure to contribute to the househol's income. Whether this is the correct explanation has to be analysed in further studies. Another effect of the baseline regressions can be confirmed for cohabiting women. Women in STEM reduce their weekly working hours significantly less if they have young children. However, the size of the estimated coefficient is smaller for cohabiting women compared to the baseline models. A similar motivation as mentioned for the overall effect of working in STEM may apply here, too.

Further robustness checks were conducted by excluding women born in 1985 or later. By excluding young women, the fact that some of these cohorts may not have finished their education during the survey is taken into account. The estimation results do not differ significantly from the baseline models. In a final step, women from Eastern Europe were excluded from the estimation sample because of their surprising effect on the descriptive means. Even if the magnitude of the coefficients concerning the variable "working in STEM" decrease slightly, the pattern of signs and significance stay similar. In reference to these robustness checks, the author finds that the estimation results are stable to many changes in restrictions conerning the data set.

\section{Conclusions}

This paper analyses the determinants of the labour supply of women in STEM. The empirical analysis applies the estimation method developed by Blundell et al. (1998) and, therefore, controls for unobserved heterogeneity and selection effects in occupations and employment. The author finds empirical evidence for the endogeneity of wages and of labour participation. Therefore, a grouping estimator is necessary to ensure consistent estimates. Using data from the EU-SILC, the results show that women in STEM are less likely to participate in the labour force but, if working, work significantly more hours per week. Additionally, the empirical analysis shows that women in STEM decrease their labour supply significantly less if they have small children.

The empirical analysis also focusses on different institutional settings. To test the effect of policies, the author compares women in different member states of the EU. The author finds empirical evidence for an increase in weekly working hours if governments increase expenditures on childcare. A significantly negative effect is found for the percentage of GDP spent on family allowance. Women in STEM work fewer hours in countries with higher levels of family allowances compared to other women. However, this effect is small in size compared to the overall effects of higher levels of expenditures on family allowance and child benefits.

This paper, therefore, contributes to the scientific understanding of differences in the employment behaviour between occupational groups. The focus on STEM is chosen 
because of the high relevance of these occupations for industrialised economies. Policymakers and business people would like to increase the quantity of young women choosing occupations in STEM partly because of demographic change. In times of aging societies and shrinking labour forces, the quantity and quality of workers in key industries such as STEM are critical issues for the economy's future growth and welfare. This understanding is necessary to ensure that women who graduate in STEM fields remain workers in STEM occupations and take advantage of high earnings and career possibilities. The empirical analysis shows that popular family policies like the enlargement of childcare and family allowances do not affect the employment behaviour of women in STEM in the same way as other women - even if the negative effect of family allowances is more ponounced in this group. So, different family policies are needed to enlarge the employment of women in STEM. One idea can be a deeper involvement of companies in the development of work-life-concepts or the offer of reintegration after maternal leave for women in STEM.

In summary, more studies are needed that focus on differences in the female employment behaviour between occupations. One aspect that needs to be examined in future studies is the impact of tax benefits and social security systems on women's labour supply with respect to their occupations. A solid scientific understanding is needed to design policies and campaigns that meet the needs of the occupational group in focus. Groupspecific employment behaviour must be taken into account if policies are to produce the desired outcomes.

\section{Endnotes}

${ }^{1}$ For technical details with regard to the derivation and characteristics of the estimator, see Blundell et al. (1998).

${ }^{2}$ See Heckman (1979) for details on estimation techniques.

${ }^{3}$ For a detailed description of technical details, see Schlenker (2014).

${ }^{4}$ The occupation of the individuals' current main job, or individuals' last job if they are not currently working, is coded via ISCO-88 on a two-digit-level in the EU-SILC.

Because individuals are not asked to name their educational fields, I cannot measure whether the women have a degree in STEM but do not work in a related job.

${ }^{5}$ Only children living in the same household can be taken into account when using data from the EU-SILC. There is no variable included in the EU-SILC that indicates an individual's number of biological children. However, children living in the same household require the most care in terms of childcare and housework.

${ }^{6}$ The hourly wage is calculated as the yearly net wage divided by the number of weekly hours multiplied by 48.

${ }^{7}$ Engel and Schaffner (2012) propose a correction for this problem that I have tried to apply. However, the correction implemented economically implausible results such as a negative correlation between hourly wages and hours worked or a correlation of approximately zero between wages (referring to the past year) and corrected hourly wages. This is most likely caused by the large number of dropped individuals, following the approach of Engel and Schaffner (2012).

${ }^{8}$ Access to the data used is available via http://ec.europa.eu/eurostat/data/database.

${ }^{9}$ All presented models include robust standard errors. The reviewer raised the issue that due to the inclusion of national-level variables, clustered standard errors should be used. The author checked this point and also finds significant effects for the individual-level variables when clustered standard errors are used. The estimation results are available in Table 7. 
${ }^{10}$ The macro variables are taken from the online database of Eurostat. The percentages of GDP spent on family allowance and the percentage of GDP spent on childcare are available via the codes "STTCPALLOW" and "STTKCHILD". Both data belong to the category "spr_exp_ffa". The information on the percentage of women in employment and on the percentage of women working part-time is coded "lfsa_argan" and "lfsa_eppga", respectively. The country's percentage of women in STEM is computed from the data set.

${ }^{11}$ The reviewer presented the aspect of endogeneity that can arise from the national-level data. The reason can be the simultaneity of the availability of childcare. Because this aspect cannot be completely condemned, the causal interpretation of the national-level variable should be neglected.

${ }^{12}$ Due to space restrictions, the estimation results are not included in the paper but are avilable upon request. The author is thankful to the reviewer who raised that issue.

${ }^{13}$ The author does not only refer to married women because marriage has become a less popular family model in many European countries during the last 20 years. Therefore, many women who live with a partner and can, therefore, pool their earnings would be excluded because of the missing legal status.

\section{Competing interests}

The IZA Journal of European Labor Studies is committed to the IZA Guiding Principles of Research Integrity. The author declares that she has observed these principles.

\section{Acknowledgements}

Financial support from BMBF and ESF is gratefully acknowledged (Förderkennzeichen 01FP1042/43). The author is also thankful to helpful comments of an anonymous reviewer, Gerhard Wagenhals, Nadine Riedel, Ulrich Scheurle and all participants of the "Hohenheimer Doktoranden Kolloquium".

Responsible editor: Sara de la Rica

Received: 14 July 2014 Accepted: 27 February 2015

Published online: 12 June 2015

References

Altonji JG, Blank RM (1999) Race and gender in the labor market. In: Ashenfelter O, Card D (eds). Handbook of Labor Economics, vol 3C. North Holland, Amsterdam, chap 48. Elsevier. pp 3143-3259

Arrow KJ (1972) Models of job discrimination. In: Pascal AH (ed). Racial Discrimination in Economic Life, D. C. Heath. D.C. Heath, Lexington, MA. pp 83-102

Badescu M, D'Hombres B, Villalba E (2010) Returns to education in European countries - evidence from the European community statistics on income and living conditions (EU-SILC). Working Paper, Joint Research Centre of the European Commission, Brussels

Becker GS (1957) The economics of discrimination. University of Chicago Press, Chicago

Bergman M, Hupka-Brunner S, Kanji S (2012) Gender differences in the transition from secondary to post-secondary education: The case of Switzerland. Working Paper, OECD, Paris

Bertrand M (2011) New perspectives on gender. In: Ashenfelter OC, Card D (eds). Handbook of Labor Economics, vol 4B. North Holland, Amsterdam, chap 17. Elsevier. pp 1543-1590

Bick A, Fuchs-Schündeln N (2012) Taxation and labor supply of married women across countries: a macroeconomic analysis. Working paper 9115, Centre for Economic Policy Research, London

Blundell R, Duncan A, Meghir C (1998) Estimating labor supply responses using tax reforms. Econometrica 66(4):827-861

Carrell SE, Page ME, West JE (2010) Sex and science: how professor gender perpetuates the gender gap. Q J Econ 125(3):1101-1144

Chevalier A (2012) To be or not to be... a scientist? Working paper 6353, Institute for the Study of Labor, Bonn

Cordero R, DiTomaso N, Farris GF (1994) Career development opportunities and likelihood of turnover among R\&D professionals. IEEE Trans Eng Manag 41(3):223-233

Engel M, Schaffner S (2012) How to use the EU-SILC panel to analyse monthly and hourly wages. Working Paper 390, Rheinisch-Westfälisches Institut für Wirtschaftsforschung, Essen

Esping-Andersen G (1990) Social foundations of postindustrial economies. Polity Press, Cambridge

Esping-Andersen, G (1999) The three worlds of welfare capitalism. Oxford University Press, Oxford

Fernandez T, Bucheli M, Cardozo S (2012) Gender differences in the transition from secondary to post-secondary education: The case of Uruguay: A pisa longitudinal study. Working paper, OECD, Brussels

Glocker D, Steiner V (2011) Returns to education across Europe: A comparative analysis for selected EU countries. Working paper 15, Free University Berlin, Berlin

Görlitz K, Grave BS (2012) Wage differentials by field of study - the case of German university graduates. Educ Econ 20(3):284-302

Haffner Y, Könekamp B, Krais B (2006) Arbeitswelt in Bewegung. Chancengleichheit in technischen und naturwissenschaftlichen Berufen als Impuls für Unternehmen. German Federal Ministry of Education and Research, Bonn

Heckman JJ (1979) Sample selection bias as a specification error. Econometrica 47(1):153-161 
Jackson LA, Gardner PD, Sullivan LA (1993) Engineering persistence: past, present, and future factors and gender differences. Higher Educ 26(2):227-246

Legewie J, DiPrete TA (2014) The High School Environment and the Gender Gap in Science and Engineering. Sociology of Education 87(4):259-280

Leslie LL, McClure GT, Oaxaca RL (1998) Women and minorities in science and engineering, a life sequence analysis. J Higher Educ 69(3):239-276

Minks KH (1996) Frauen aus technischen und naturwissenschaftlichen Studiengängen - Ein Vergleich der Berufsübergänge von Absolventinnen und Absolventen, vol 116. Hochschulplanung, Hannover

Minks, K H (2001) Ingenieurinnen und Naturwissenschaftlerinnen - neue Chancen zwischen Industrie- und Dienstleistungsgesellschaft: Ergebnisse einer Längsschnittuntersuchung zur beruflichen Integration von Frauen aus technischen und naturwissenschaftlichen Studiengängen, vol 153. Hochschulplanung, Hannover

Mroz TA (1987) The sensitive of an empirical model of married women's hours of work to economic and statistical assumptions. Econometrica 55(4):765-799

OECD (2012) Closing the Gender Gap: Act Now. OECD Pubblishing, Paris

Phelps ES (1972) The statistical theory of racism and sexism. Am Econ Rev 62:659-661

Polachek SW (1981) Occupational self-selection: A human capital approach to sex differences in occupational structure. Rev Econ Stat 63(1):60-69

Schlenker E (2009) The labour supply of female engineers in Germany. Austrian J Stat 38(4):255-264

Schlenker, E (2014) Essays on Occupational Choice. SVH Südwestdeutscher Verlag für Hochschulschriften, Saarbrücken

Smith RJ, Blundell R (1986) An exogeneity test for the simultaneous equation tobit model. Econometrica 54(3):679-685

Tsai C, Hung M, Harriott K (2010) Human capital composition and economic growth. Soc Indicator Res 99(1):41-59

Wagenhals G (2000) Arbeitsangebotseffekte des Steuer- und Transfersystems in der Bundesrepublik Deutschland. Jahrbücher für Nationalökonomie und Statistik 220(2):191-213

Wagenhals, G (2011) Dual income tax reform in Gemany. a microsimulation approach. Int J Microsimulation 4(2):3-13

Wahrenburg M, Weldi M (2007) Return on investment in higher education - evidence for different subjects, degrees and gender in Germany. Working Paper 709, Goethe University of Frankfurt, Frankfurt

\section{Submit your manuscript to a SpringerOpen ${ }^{\circ}$ journal and benefit from:}

$\checkmark$ Convenient online submission

- Rigorous peer review

- Immediate publication on acceptance

- Open access: articles freely available online

High visibility within the field

- Retaining the copyright to your article

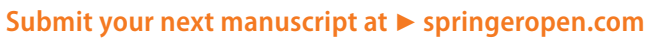

